\title{
Andrzej Grzegorczyk
}

Muzeum Tradycji Niepodległościowych w Łodzi, Oddział Stacja Radegast https://orcid.org/0000-0001-7554-6516

a.grzegorczyk@muzeumtradycji.pl

\section{Nowa wystawa stała w Muzeum byłego niemieckiego Obozu Zagłady Kulmhof w Chełmnie nad Nerem}

\begin{abstract}
Streszczenie
Obóz zagłady Kulmhof w Chełmnie nad Nerem ze względu na rolę, jaką odegrał w okresie Holokaustu, stanowi przestrzeń unikatową. Pomimo ogromu dokonanych w nim zbrodni miejsce to uległo deprecjacji w okresie powojennym. W ostatnich latach nastąpiła intensyfikacja działań zmierzających do jego należytego upamiętnienia. Jednym z elementów tego procesu było udostępnienie w 2019 r. w przestrzeni poobozowej stałej ekspozycji historycznej, o której traktuje niniejszy tekst.
\end{abstract}

\section{Słowa kluczowe}

wystawa stała, obóz zagłady, Kulmhof, Chełmno nad Nerem

\begin{abstract}
The Kulmhof death center in Chełmno nad Nerem is a unique space due to the role it played during the Holocaust. Despite the magnitude of the crimes committed there, it underwent a depreciation during the postwar period. Recent years have brought an intensification of efforts to properly commemorate this place of memory, for instance, the 2019 opening of a permanent historical exhibition in the place where the camp used to be located and which this text concerns.
\end{abstract}

\section{Key words}

permanent exhibition, death center, Kulmhof, Chełmno nad Nerem

Dawny obóz zagłady Kulmhof w Chełmnie nad Nerem ze względu na rolę, jaką odegrał w okresie Holokaustu, stanowi przestrzeń unikatową. Pomimo ogromu dokonanych na jego terenie zbrodni pamięć o nim w okresie powojennym nie była odpowiednio pielęgnowana. Monumentalny pomnik ku czci ofiar, wzniesiony w Lesie Rzuchowskim w 1964 r., zaświadczał o przeznaczeniu tego miejsca, jednak paradoksalnie ograniczył myślenie o nim i jego historii wyłącznie do leśnego cmentarzyska. Główna część dawnego obozu, zlokalizowana w samym Chełmnie nad Nerem, pozostawała przez dziesięciolecia w prywatnych rękach, praktycznie poza wszelką możliwością upamiętnienia. Powolna zmiana tej sy- 
tuacji nastąpiła dopiero wraz z przeobrażeniami ustrojowymi, które dokonały się w Polsce po 1989 r. W połowie 1990 r. oficjalnie powstało Muzeum byłego niemieckiego Obozu Zagłady Kulmhof w Chełmnie nad Nerem (jako oddział Muzeum Okręgowego w Koninie), mieszczące się w niewielkim pawilonie wybudowanym na terenie Lasu Rzuchowskiego. Staraniem Rady Ochrony Pamięci Walk i Męczeństwa kupiono, a następnie przekazano na cele muzealne teren dawnego majątku ziemskiego w Chełmnie będącego zasadniczą częścią ośrodka eksterminacyjnego. Należy przy tym zauważyć, że nastąpiło to dopiero w końcu $1998 \mathrm{r}$. $\mathrm{W}$ kolejnych latach intensywnie prowadzone badania archeologiczne doprowadziły do rozpoznania całego obszaru. W 2004 r. przystąpiono do zabezpieczenia spichlerza, jedynego ocalałego po wojnie obiektu związanego z funkcjonowaniem obozu. W jego wnętrzach powstała wówczas pierwsza, tymczasowa wystawa prezentująca kolekcje przedmiotów pozyskanych w wyniku prac terenowych.

W 2013 r. decyzją marszałka województwa wielkopolskiego wydzielono to miejsce pamięci ze struktur konińskiej instytucji kultury, powierzając opiece Muzeum Martyrologicznego w Żabikowie. Pozwoliło to na wzmożenie prac renowacyjnych i edukacyjno-wydawniczych. Wzniesiono dwa budynki na potrzeby dydaktycznej i administracyjnej działalności oddziału. Dotychczasowe dwa niewielkie obiekty wykorzystywane na cele muzealne poddano pracom remontowym, dostosowując je do pełnienia nowych funkcji: niewielkiego centrum przyjęcia odwiedzających oraz pawilonu edukacyjnego w Lesie Rzuchowskim. Przeprowadzono prace konserwatorskie: zrewitalizowano spichlerz, przywracając jego pierwotny wygląd i układ architektoniczny; wytyczono nowe miejsca pamięci zgodnie z rzeczywistą lokalizacją grobów masowych; zabezpieczono niszczejące ruiny pałacu będącego głównym budynkiem obozowym, udostępniając ich zwiedzenie z wykorzystaniem specjalnej kładki itp. W ostatnich latach Muzeum wydało również kilka pozycji o charakterze edukacyjnym, prowadząc liczne kwerendy, których owocem są publikacje historyczne.

Zamknięciem tego, jak można określić, początkowego etapu rewitalizacji było udostępnienie stałych ekspozycji traktujących o dziejach Kulmhof. Pierwsza z nich, „Spichlerz - przestrzeń tragedii”, mojego autorstwa wraz z oprawą plastyczną Wawrzyńca Kozickiego, powstała w 2016 r. Stanowiła ona część projektu renowacji dawnego spichlerza, a jej otwarcie nastąpiło w 75. rocznicę pierwszego transportu ofiar. Wystawa poświęcona losom spichlerza i wydarzeniom, które odbywały się w jego wnętrzach, w szczególności likwidacji obozu w nocy z 17 na 18 stycznia 1945 r., od początku była planowana jako element szerszej prezentacji.

W grudniu 2019 r. w części muzealnej mieszczącej się we wsi Chełmno udostępniono pierwszą stałą wystawę monograficzną, „«To są ostatnie dni naszego życia, dajemy więc znać o sobie». Kulmhof - początek Zagłady". Za jej scenariusz odpowiadałem ja, zaś koncepcję wizualną przygotował Wawrzyniec Kozicki. Ekspozycja została ulokowana w jednej, relatywnie niewielkiej, bo liczącej tylko $100 \mathrm{~m}^{2}$ sali w nowo powstałym budynku muzealnym. Na początkowym etapie 
musieliśmy się zmierzyć z przestrzenią, która samoistnie narzuciła dalszy rozwój układu kompozycyjnego. Przyjęliśmy optymalne rozwiązanie, rezygnując z wyraźnego wyodrębnienia poszczególnych stref ekspozycyjnych (co byłoby możliwe przy większej liczbie pomieszczeń) na rzecz aranżacji składającej się z kręgów prowadzących do centrum sali. Wizualna prezentacja ma charakter tradycyjny, wykorzystaliśmy w niej oryginale zabytki obozowe zamiast komponentów multimedialnych. Tym samym wyraźnie wskazaliśmy na najważniejszy element całej ekspozycji - ocalałe rzeczy osobiste ofiar, materialne świadectwa Zagłady.

Również tytuł, „To są ostatnie dni naszego życia, dajemy więc znać o sobie”, nawiązuje do jednego $\mathrm{z}$ niewielu zachowanych przekazów pochodzących od Żydów zmuszonych do pracy na rzecz obozu. Słowa te, zaczerpnięte z krótkiej notatki zrobionej na małej kartce w piwnicy pałacowej nie wcześniej niż w lipcu 1942 r., sygnalizują zbliżającą się śmierć dla zebranej w tym miejscu grupy więźniów. Nieznany autor pozostawia ślad, aby chociaż w ten sposób opowiedzieć o swoim losie. W założeniu wystawa koresponduje z tym przesłaniem, przedstawiając dzieje Kulmhof z perspektywy ofiar. Ma ona charakter narracyjny, oddając pierwszeństwo głosom z przeszłości przed współczesnym komentarzem odautorskim. Ten z kolei jest ograniczony do minimum, nastawiony jedynie na zobrazowanie szerszego tła zjawisk przywoływanych w relacjach.

Pierwotnie naszym celem było przybliżenie historii obozu na podstawie ówczesnych świadectw. Jednak niezachowana dokumentacja obozowa, fragmentaryczne materiały z innych źródeł wpłynęły na szersze wykorzystanie powojennych danych. Wśród nich bezcenne są informacje i zeznania zebrane przez sędziego Władysława Bednarza w latach 1945-1946 w trakcie śledztwa w sprawie zbrodni dokonanych w Kulmhof. Dominujący głos uczestników wydarzeń (w tym przede wszystkim ofiar) został skonfrontowany ze wspomnieniami świadków, polskich lub niemieckich mieszkańców Chełmna oraz jego okolic. Ukazując powiązania lokalnej społeczności z funkcjonującym obozem, można zaprezentować różne perspektywy postrzegania tego miejsca, ujawnić wiedzę o nim. Szczególny punkt widzenia przedstawiają wypowiedzi sprawców, którzy używają języka propagandy. Takie spojrzenie, pod względem etycznym nieakceptowalne, pozwala jednak na uwzględnienie niektórych aspektów działalności obozu znanych wyłącznie jego załodze.

Na wizualną część wystawy składają się głównie fotografie wykonane przez samych Niemców, najczęściej w celach dokumentacyjnych lub pamiątkowych, bądź zrobione już po likwidacji obozu w ramach prowadzonego śledztwa. Każdorazowo pojawiają się obok nich fragmenty relacji komentujące, a najczęściej uzupełniające zdjęcia. Drugim bardzo ważnym elementem wizualnym są towarzyszące poszczególnym historiom oryginalne obiekty prezentowane w odrębnych niszach ekspozycyjnych.

Zagadnienia skoncentrowane na eksterminacji realizowanej „tu i teraz” są przedstawione w układzie chronologiczno-problemowym, w którym Kulmhof staje się w mikroskali synonimem Holokaustu. Skierowanie całej uwagi na obóz 
wymusiło na nas dodanie rozdziału otwierającego, "Chełmno przed Zagładą”, poświęconego dziejom wsi do grudnia 1941 r. Dzięki niemu odbiorca ma szansę zapoznać się z historią miejscowości. Tym samym wieś nabiera charakteru żywego organizmu, nie będąc tylko tłem dla działalności ludobójczej. Dalsze bloki narracyjne są już jednak ściśle powiązane z funkcjonowaniem Kulmhof. Część zatytułowana „Organizacja obozu (1941)” koncentruje się na związkach akcji eutanazji osób psychicznie chorych z późniejszą Zagładą, kwestiach utworzenia obozu (w ramach oddolnej inicjatywy niemieckiej administracji lokalnej tzw. Kraju Warty), jego lokalizacji na skraju wsi wokół zamieszkanych zabudowań oraz wypływających z tego konsekwencjach, a przede wszystkim na jego strukturze organizacyjnej. Kolejne bloki, „Deportacje do obozu (1941-1943)” i „Ponowne uruchomienie i działalność obozu (1944-1945)”, obrazują proces eksterminacji w dwóch oddalonych od siebie miejscach (we wsi Chełmno oraz w Lesie Rzuchowskim wykorzystywanym jako cmentarzysko) narzucających określoną technikę i logistykę prowadzonej akcji. Końcowy fragment, poświęcony wydarzeniom związanym z likwidacją obozu, jedynie sygnalizuje szerszą treść dostępną na wystawie w budynku spichlerza. Zagłada jest ukazana jako proces, począwszy od organizacji terenu, poprzez deportacje Żydów z gett, do ostatnich chwil przed ich zamordowaniem. W ten sposób odbiorca może się zapoznać na podstawie materiałów faktograficznych z historią obozu.

W celu przybliżenia istoty i działalności Kulmhof elementy zostały umieszczone w oddzielnych, samodzielnych strefach. Dotyczą różnych zagadnień, m.in. prezentują informacje o jego funkcjonowaniu (w tym także te, które dotarły do getta warszawskiego dzięki pierwszym zbiegom), biografie sprawców i ocalałych uciekinierów. Osobno został również poruszony problem tzw. Polnische Arbeits kommando, grupy tworzonej przez ośmiu Polaków, więźniów pełniących pomocnicze funkcje obozowe. Niektóre z przywoływanych tematów korespondują $\mathrm{z}$ dziejami tego miejsca, lecz w swoim charakterze wykraczają poza sam obóz. W ten sposób zostały przedstawione: kwestia rabowanego mienia i roli w tym procederze niemieckiego Zarządu Getta w Łodzi, eksperymenty z zacieraniem śladów zbrodni (prowadzone w ramach Akcji 1005), postać Stanisława Kaszyńskiego, przedwojennego sekretarza gminy w Chełmnie, który przekazał polskiemu podziemiu pierwsze wiadomości o Kulmhof. Wątki zamyka historia deponowania i niszczenia przez załogę obozu na jego terenie rzeczy osobistych ofiar oraz wybiegający już po 1945 r. passus o losach tej przestrzeni. Ostatni, centralny element wystawy tworzą zestawione ze sobą fragmenty relacji czterech Ocalałych: Michała Podchlebnika, Szymona Srebrnika, Mieczysława Żurawskiego, a przede wszystkim Szlamka Winera. Skonfrontowane ze sobą układają się w całość obrazu ostatecznego aktu eksterminacji. Różnią je perspektywy, ale pozostają ze sobą komplementarne, oddając ogrom Zagłady. W ten sposób, pomimo naturalnych ograniczeń wynikających z selekcji materiału, doboru treści oraz zastosowania takich, a nie innych środków przekazu, nadrzędną ideą przyświecającą wystawie było ukazanie dziejów obozu w najszerszej z możliwych form. 